\title{
Metaphors: The Elementary School Teacher Candidates Come Up with Relation to the Concept of "Drama"
}

\author{
Ayşe Mentiş Taş \\ Konya Necmettin Erbakan Üniversity, Meram Yeniyol/Konya, Turkey \\ Email: aysementistas@hotmail.com
}

Received February $22^{\text {nd }}, 2013$; revised March $23^{\text {rd }}, 2013$; accepted April $1^{\text {st }}, 2013$

\begin{abstract}
Copyright (c) 2013 Ayșe Mentiş Taş. This is an open access article distributed under the Creative Commons Attribution License, which permits unrestricted use, distribution, and reproduction in any medium, provided the original work is properly cited.
\end{abstract}

\begin{abstract}
The purpose of this study is to uncover the perceptions of the elementary school teacher candidates who have related to the concept of "drama" through metaphors. The study group consisted of 129 third-year students taking the "Drama" course during the fall semester of the 2012-2013 academic year in the Department of Elementary School Teaching of Necmettin Erbakan University's Faculty of Education. 66 of the teacher candidates, who participated in the study, were females and the 63 of them were males. The data of the study was obtained by students completing the sentence of "Drama is like... because...". To do this, the teacher candidates were given a blank sheet of paper with the aforementioned sentence written at the top of the paper and were asked to express their thoughts by using that statement and by concentrating on only one metaphor. During the analysis of the data, frequency, percentage calculations and content analysis which is a qualitative method, were used. The process of analyzing and interpreting the metaphors developed by the teacher candidates was carried in five phases: (1) naming stage, (2) screening and clarifying phase, (3) compiling and category development phase, (4) proving the validity and reliability phase, (5) transferring the data into the computer. According to the findings of the study, the teacher candidates developed 30 valid metaphors related to the concept of "Drama". These metaphors were then grouped under five different conceptual categories after examining them in terms of common characteristics.
\end{abstract}

Keywords: Drama; Metaphor; Elementary School Teacher; Teacher Candidate

\section{Introduction}

Today, education systems follow a student-centered approach not a teacher-centered approach. Therefore, what is needed from the students is for them to be individuals who are active and confident and who know the ways to reach information, apply the knowledge and skills they have learned, decide, take responsibilities, communicate, work collaboratively and learn-bydoing. For students to gain these characteristics, student-centered methods should be used in classrooms. One of the student-centered methods that forces the students to be active, allows them to learn-by-doing and helps them to communicate positively with others and socialize is drama.

Drama is action situations and improvisations that the participants create based on their own creative inventions, original thoughts, memories and knowledge without a prior written text (San, 1999). Drama is a teaching method among contemporary methods that is student-centered and that makes the learner active and ensures permanent learning by learning-by-doing and having fun (Maden, 2011).

Drama is the most significant model of learning and is a basic activity for learning. It is the way of helping children to think about their individual or social problems. Children can learn to explore issues, events and connections by means of drama. In drama, children draw on their knowledge and experience of the real world in order to create a make believe world (O’Neill \& Lambert, 1989, cited in Üstündağ, 1997).

The general purpose of drama, which enables the children to go back and forth between the real world and the fictional world, is to have individuals who are creative in all areas, selfsufficient, self-aware, articulate and communicative. With these characteristics, drama provides significant contributions to the child by supporting the child's development and creativity (Brewer, 2007).

The use of drama as a teaching method in elementary schools can create personal and social development environments such as working together, sharing and "self-realizations". Drama education is open to new ideas, individual decisions and opportunities for free choice. In that respect, drama helps the students to look at the world from many perspectives and to live their own feelings and emotions in a realistic environment (Üstündağ, 1997).

Being done in every educational level and with people from all ages, drama studies can be integrated with the modern education system and can create teachers and students who have a need and excitement to improve themselves by breaking the boring structures of education (Okvuran, 1995).

Today, drama can be done starting from pre-school to postgraduate in all levels of education. In elementary school, drama is included in courses such as life studies, science, math, social studies and music. However, for drama to be used in schools, the teachers have to be knowledgeable about drama. For this 
purpose, in Turkey some changes have been made in higher education (Ormanc1 \& Ören, 2010).

With the "Restructuring of Education Faculties" made by CHE (The Council of Higher Education), "Drama in preschool" and "Drama in Elementary School" courses were made compulsory in undergraduate programs of education faculties. This can be regarded as an important point where Turkey came in regards to academic level (Adigüzel, 1999). After the new regulations in higher education, elementary school teacher candidates have been taking "Drama" course in their $3^{\text {rd }}$ year $\left(5^{\text {th }}\right.$ semester). After this development, there has been a lot of research done on drama. Many of the research done in Turkey regarding drama is about the effectiveness of drama as a method and the drama application skills of the teachers (Gürol, 2003; Harun, 2005; Dalbudak, 2006; Yılmaz, 2006; Erdoğan, 2006; Akyol \& Hamamci, 2007; Kara \& Çam, 2007; Yildirim, Sedef, \& Can; Özdemir \& Çakmak, 2008; Dalbudak \& Akyol, 2008; Yildirım, 2008; Karacil, 2009; Çelen \& Vural, 2009; Ormanci \& Ören, 2010; Dellal \& Kara, 2010; Aykaç \& Adigüzel, 2011; Oğuz \& Altun, 2011).

There is not much research on drama and metaphorical thinking. Metaphor is a perception tool (Arnett, 1999). What is meant by the concept of metaphor is explaining a concept, a phenomenon or an event with another concept, phenomenon or event through an analogy (Oxford et al., 1998). Metaphors can also be defined as "language of experiences" in terms of individuals giving meaning to their own personal experiences (Miller, 1987). In this context, this study tried to determine the metaphors elementary school teacher candidates' put forward related to drama.

\section{Purpose}

The purpose of this study is to uncover the perceptions of the elementary school teacher candidates have related to the concept of "drama" through metaphors. Within this general purpose, the answers for the following questions were sought:

1. Through which metaphors the elementary school teacher candidates explain their perceptions related to the concept of "drama"?

2. In which conceptual categories these metaphors can be grouped under in terms of common characteristics?

\section{Method}

\section{Study Group}

This study was carried out within the framework of "content analysis" model, which is a qualitative research approach. The study group of the research consisted of 129 third-year students taking the "Drama" course during the fall semester of the 2012-2013 academic year in the Department of Elementary School Teaching of Necmettin Erbakan University's Faculty of Education. 66 of the teacher candidates, who voluntarily participated in the study, were females and the 63 of them were males.

\section{Data Collection}

For the purpose of determining the perceptions of teacher candidates related to the concept of "drama", each candidate was asked to complete the sentence of "Drama is like... because...". To do this, the teacher candidates were given a blank sheet of paper with the aforementioned sentence written at the top of the paper and were asked to express their thoughts by using that statement and by concentrating on only one metaphor. In studies that the metaphor is used as a research tool, the concept of "like" is generally used to clearly show the link between the metaphor's subject and metaphor's source (Saban, 2008). In this study, by also including the concept of "because", the teacher candidates were asked to provide a justification and give a logical basis for their metaphors. The answers given by the teacher candidates were used as the main data source in this study.

\section{Data Analysis}

During the analysis of the data, frequency, percentage calculations and content analysis which is a qualitative method, were used. The process of analyzing and interpreting the metaphors developed by the teacher candidates was carried out five phases that were used by Saban (2008): (1) naming phase, (2) screening and clarifying phase, (3) compiling and category development phase, (4) proving the validity and reliability phase, (5) transferring the data into the computer phase.

Naming Phase: During this phase, a temporary list in alphabetical order was made by the metaphors created by the study group and whether the teacher candidates expressed a specific metaphor in their writings was examined. At this phase, the metaphor used by each candidate was coded (ex: life, tree, sun, mirror, pencil, etc.).

Screening and Clarifying Phase: During this phase, after reviewing the metaphors created by the teacher candidates, each metaphor's image (1) was analyzed in terms of metaphor's subject (2), metaphor's source (3) and the relationship between metaphor's subject and source. 15 teacher candidates' papers were excluded form the study for not giving metaphor examples, not giving justifications/reasons for their metaphors and for their reasons not concurring with their metaphors.

Compiling and Category Development Phase: As a result of examining teacher candidates' papers, 30 valid metaphor images were retrieved. These metaphors were grouped under five different categories based on their common characteristics.

Proving the Validity and Reliability Phase: Validity and reliability are the two most important criterion used to ensure the credibility of a research's results. In a qualitative study, reporting the collected data in detail and explaining how the researcher reached the results are among the important criterion of validity" (Yıldırım \& Șimșek, 2005). In this study, to ensure the validity of the data, the data analysis process was explained in detail and all the metaphors representing the identified categories were included in the findings. For the reliability of the data, two experts in the field of educational sciences were consulted. They were asked to evaluate the likeliness of the identified categories and the metaphor images grouped under these categories. Then, an agreement was achieved by comparing the analysis of the experts. Determining the number of agreements and number of disagreements in comparisons, the study's reliability was calculated by using Miles and Huberman formula (reliability $=$ agreement/agreement + disagreement). In the reliability study specific to this research, $90 \%$ of agreement (reliability) was obtained.

Transferring the Data into the Computer Phase: After determining a total of 30 categories and creating the conceptual categories of these metaphors, all the data was entered into the 
computer and $\mathrm{f}$ and $\%$ values were calculated by placing the teacher candidates' valid metaphors into categories.

\section{Findings}

In this section, frequency and percentage distribution information related to teacher candidates' metaphors about the concept of drama and the distribution of these metaphors by categories is given.

Table 1 shows the first three metaphors created by teachers candidates. These life, dream and mirror.

Table 2 shows teacher candidates created 30 metaphors related to the concept of drama. These metaphors were then grouped under five categories after taking the logical reasons suggested into consideration.

Table 3 shows four metaphors were created by a total of 23 students. In this category, mirror is the most created metaphor. The following are examples of the teacher candidates' reasons using these metaphors.

Table 1.

Frequency and percentage distributions of teacher candidates' metaphors related to the concept of drama.

\begin{tabular}{cccccc}
\hline Metaphor Name & f & $\%$ & $\begin{array}{c}\text { Metaphor } \\
\text { Name }\end{array}$ & f & $\%$ \\
\hline Mirror & 16 & 14 & Orchestra & 1 & 0.9 \\
Paint Palette & 2 & 1.7 & Play Dough & 5 & 4.4 \\
Chameleon & 2 & 1.7 & Toy & 1 & 0.9 \\
Flower Garden & 3 & 3.7 & Teacher & 1 & 0.9 \\
Chocolate & 1 & 0.9 & Cake & 2 & 1.7 \\
Child & 3 & 2.7 & Window & 2 & 1.7 \\
Football & 5 & 4.4 & Piano & 1 & 0.9 \\
Night Lamp & 1 & 0.9 & Colors & 4 & 3.5 \\
Rainbow & 2 & 1.7 & Water & 4 & 3.5 \\
Sun & 5 & 4.4 & Sponge & 1 & 0.9 \\
Dream & 19 & 16.4 & Song & 1 & 0.9 \\
Pencil & 3 & 2.7 & Poem & 1 & 0.9 \\
Book & 2 & 1.7 & Television & 1 & 0.9 \\
Fruit Tree & 2 & 1.7 & Rain & 1 & 0.9 \\
School & 1 & 0.9 & Life & 21 & 18.4 \\
Total & $\mathbf{1 1 4}$ & & & & 100 \\
\hline
\end{tabular}

Table 2.

Distribution of teacher candidates' metaphors related to drama by categories.

\begin{tabular}{lcc}
\hline Category Name & $\begin{array}{c}\text { f Created } \\
\text { Metaphor }\end{array}$ & \% \\
\hline Reflection & 4 & 13.3 \\
Teaching and Informing & 8 & 26.7 \\
Entertaining & 5 & 16.6 \\
Collaboration & 2 & 6.7 \\
Expressing Different Roles and Feelings & 11 & 36.7 \\
Total & 30 & 100 \\
\hline
\end{tabular}

Table 3.

Reflection.

\begin{tabular}{ccc}
\hline Metaphor Name & $\begin{array}{c}\text { f Students Representing } \\
\text { the Metaphor }\end{array}$ & \% \\
\hline Mirror & 16 & 14.03 \\
Window & 2 & 1.7 \\
Water & 4 & 3.5 \\
Sponge & 1 & 0.9 \\
Total & $\mathbf{2 3}$ & $\mathbf{2 0 . 1 3}$ \\
\hline
\end{tabular}

Drama is like a mirror because mirror shows everything as it is. Drama shows a person every aspect of themselves, too. (S.N. 45)

Drama is like a window because when we look out the window, we see the world. When we watch drama, we see the truth. (S.N. 22)

Drama is like a sponge because it sucks the realities of the world, in a way it, filters them and lets them go. (S.N. 37)

Drama is like water because water is transparent. Water shows whatever you reflect on it. Drama shows the people as they are, too. (S.N. 4)

Table 4 shows eight metaphors were created by 16 students. In this category, sun is the most created metaphor. The following are examples of the teacher candidates' reasons using these metaphors.

Drama is like a night lamp because people light up through drama just like how a night lamp lightens up and shows the way. (S.N. 55)

Drama is like the sun because sun gives light to its surrounding, it lights up. Drama gives message to the people. It gives information. It helps people to light up. (S.N. 63)

Drama is like a pencil because we write book, papers and draw with pencil and this way we give out information. We give message. Drama gives us a message, too. It helps us to learn. (S.N. 84)

Drama is like a book because every book has a main idea that it gives to the reader. Drama, also, gives a main idea to the audience. (S.N. 88)

Drama is like a school because we get education in schools and we learn in schools. By taking part in drama, we and the others around us learn something. (S.N. 41)

Drama is like a teacher because a teacher educates his/her students and informs them. Drama educates and informs us, too. (S.N. 67)

Drama is alike a fruit tree because fruit is a vitamin store. Vitamins make people healthier. Drama, also, makes people more knowledgeable and cultured. (S.N. 98)

Drama is like the rain because rain falls down on the plants, nurtures them and makes them grow. With the messages it gives, drama nurtures them and helps them grow. (S.N. 106)

Table 5 shows five metaphors were created by eight students. In this category, child is the most created metaphor. The following are examples of the teacher candidates' reasons using these metaphors.

Drama is like chocolate because while we take part in drama or while we watch drama, we take the pleasure we take from chocolate. We have fun. We become happy. (S.N. 13)

Drama is like a child because drama is natural and fun like a child. Kids act naturally as it comes to them. They are at the 
Table 4.

Teaching and informing.

\begin{tabular}{ccc}
\hline Metaphor Name & $\begin{array}{c}\text { f Students Representing the } \\
\text { Metaphor }\end{array}$ & \% \\
\hline Night Lamp & 1 & 0.9 \\
Sun & 5 & 4.4 \\
Pencil & 3 & 2.7 \\
Book & 2 & 1.7 \\
School & 1 & 0.9 \\
Teacher & 1 & 0.9 \\
Fruit Tree & 2 & 1.7 \\
Rain & 1 & 0.9 \\
Total & $\mathbf{1 6}$ & $\mathbf{1 4 . 1}$ \\
\hline
\end{tabular}

Table 5.

Entertaining.

\begin{tabular}{ccc}
\hline Metaphor Name & $\begin{array}{c}\text { f Students Representing the } \\
\text { Metaphor }\end{array}$ & \% \\
\hline Chocolate & 1 & 0.9 \\
Child & 3 & 2.7 \\
Cake & 2 & 1.7 \\
Toy & 1 & 0.9 \\
Television & 1 & 0.9 \\
Total & $\mathbf{8}$ & $\mathbf{7 . 1}$ \\
\hline
\end{tabular}

same time very fun beings. Drama is natural and fun, too. (S.N. 27)

Drama is like a cake because eating cake is something fun for me. I would be happy with the taste left in my mouth. While I take part in drama, I have fun and I become happy. (S.N. 18)

Drama is like a toy because toys allow children to have fun and makes them happy. Likewise, drama allows us to have fun and makes us happy, too. (S.N. 5)

Drama is like television because television entertains us by giving us a good time. While we take part in drama we have dun and have a good time, too. (S.N. 34)

Table 6 shows two metaphors were created by six students. In this category, football is the most created metaphor. The following are examples of the teacher candidates' reasons using these metaphors.

Drama is like football because in both of them there is collaboration and the pleasure to achieve. In both of them, the play is natural. (S.N. 51)

Drama is like football because both of them have team work. One is played in the field and the other is played on the stage. The ones who play in drama act for the same purpose just like the ones who play in football. (S.N. 8)

Drama is like an orchestra because the musicians in the orchestra collaborate to make music. They produce together. The ones who participate in drama also perform by working together. (S.N. 39)

Table 7 shows 11 metaphors were created by 61 students. In this category, life and dream are the most created metaphor. The following are examples of the teacher candidates' reasons using these metaphors.
Table 6.

Collaboration

\begin{tabular}{ccc}
\hline Metaphor Name & $\begin{array}{c}\text { f Students Representing } \\
\text { the Metaphor }\end{array}$ & \% \\
\hline Football & 5 & 4.4 \\
Orchestra & 1 & 0.9 \\
Total & $\mathbf{6}$ & $\mathbf{5 . 3}$ \\
\hline
\end{tabular}

Table 7.

Expressing different roles and feelings.

\begin{tabular}{ccc}
\hline Metaphor Name & $\begin{array}{c}\text { f Students Representing the } \\
\text { Metaphor }\end{array}$ & \% \\
\hline Paint Palette & 2 & 1.7 \\
Chameleon & 2 & 1.7 \\
Flower Garden & 3 & 2.7 \\
Rainbow & 2 & 1.7 \\
Dream & 19 & 16.6 \\
Play Dough & 5 & 4.4 \\
Piano & 1 & 0.9 \\
Colors & 4 & 3.5 \\
Song & 1 & 0.9 \\
Poem & 1 & 0.9 \\
Life & 21 & 18.4 \\
Total & $\mathbf{6 1}$ & $\mathbf{5 3 . 4}$ \\
\hline
\end{tabular}

Drama is like a paint palette because there are colors on the palette. We add beauty into the picture when we use these colors. We give meaning. The different roles performed in drama let us see the details we can not see in life just like the different colors on a palette. (S.N. 12)

Drama is like a chameleon because chameleon changes color depending on its natural environment. It takes the color of the environment it is in. In drama, people engage in different roles and feelings depending on the subject. (S.N. 28)

Drama is like a flower garden because in a flower garden there are all sorts of colorful flowers. In a garden, there are tall, short and different colored flowers. There is a riot of colors. In drama, there are people with different roles. (S.N. 100)

Drama is like a rainbow because rainbow is colorful. It has all the colors of life. Drama is also colorful just like the rainbow. It has different roles and different faces. (S.N. 45)

Drama is like a dream because every person dreams. In their dreams, they take on different roles and show different emotions. In drama, people can take on different roles, too. They can perform different characters. (S.N. 38)

Drama is like play dough because play dough takes the shape of whatever you shape it into. Sometimes we can make a smiling face and sometimes we can make a sad face. In drama, we give shape to the roles we play just like giving shape to play dough. (S.N. 52)

Drama is like a piano because piano brings out many different songs. When someone plays the piano, it leaves a pleasant sound in our ears. In drama, different roles and different emotions in the performances leave a pleasant impression on us. (S.N. 72) 
Drama is like colors because each color has a different appearance and different beauty. In drama, each performance and each role has a different beauty. (S.N. 78)

Drama is like a song because sometimes the songs make us sad and sometimes they make us laugh. It is the same with drama. Some roles in drama make us laugh and some roles make us cry. (S.N. 69)

Drama is like a poem because when we reread a poem, we get a different taste and different meaning. Drama is just the same. When you rewatch it, we get different feelings and meanings. (S.N. 39)

Drama is like life because in life there are feelings like love, hate, longing, pain, sorrow, compassion and mercy. There are many roles that give these feelings. In drama, there are also many roles and there are many feelings that express these roles. (S.N. 94)

\section{Discussion and Result}

According to the findings obtained from the content analysis, the 30 metaphors created by the teacher candidates were grouped under the five categories of reflection, teaching and informing, entertaining, collaboration and expressing different roles and feelings. Among these categories, the most created metaphors were from "expressing different roles and feelings" (f: 11 , $36.5 \%$ ) and "teaching and informing" (f: 8, 26.7\%) categories.

These findings show that teacher candidates have very positive images towards the "drama" course. When the reasons the candidates gave to the metaphors are taken into consideration, it is seen that they emphasized the purposes and benefits of drama. For example, the metaphors and the reasons given in the "expressing different roles and feelings" category point to approaching events from different angles and even to empathizing. Pinciotti Similarly, in their works Pinciotti (1993) and Annarella (1992) stated that students' ability to look at events from different angles and empathize was developed through drama. In addition, Sağlam (1997), expressed that the main purpose of drama is for individuals to put themselves into other individuals' shoes and seize the opportunity to get to know themselves better. In drama, participants begin to think about people living in different circumstances and how they behave in these different circumstances by examining social events. They are able to put forward different opinions. This leads the participants to discord, discussion and solution.

According to the other findings in the study, the teacher candidates see drama as a tool to "teaching and informing". When the metaphors and the reasons given in this category are examined, it is seen that the teaching and informing aspect of drama is being emphasized. Similarly, Kaf (2000), O'Neill \& Lambert (1995), San (1996), Adıgüzel (2006), maden (2011) and Oruç \& Altin (2008) all stated that drama is a method which contributes to the development of the individual in every aspect. According to the study findings, the other categories are reflection, entertaining and collaboration. When the metaphors and the reasons given in these categories are examined, it can say that drama has entertaining, collaborative and reflective characteristics for the students. In drama, participants understand a lot of things related to themselves, their friends, their families and the world they live in by creating, developing and reflecting (Fullford et al., 2001). Along the same lines, according to Köksal (2003), drama contributes to the feelings of collaboration, solidarity and sharing in individuals. Also, according to Girgin
(1999) drama is one of the most successful group methods that allows the participants to learn by living through interaction.

As a result, the findings of this study show that the metaphors created by the teacher candidates are effective tools to explain the characteristics of drama.

\section{REFERENCES}

Adigüzel, H. Ö. (1999). Problem of creative drama teacher training in Turkey. VIII. National Educational Sciences Conference, Trabzon.

Adigüzel, H. Ö. (2006). The concept of drama, its components and phases. Journal of Creative Drama, 1, 17-31.

Akyol, A. K., \& Hamamc1, Z. (2007). The effect of drama education on the level of empathetic skills of university students. Bulgarian Journal of Science and Education Policy, 1, 205-215.

Altın, B. N., \& Oruç, S. (2008). Museum education and creative drama. Journal of Çukurova University Faculty of Education, 3, 125.

Arnett, R. C. (1999). Metaphorical guidance: Administration as building and renovation. Journal of Educational Administration, 37, 8089. doi:10.1108/09578239910253953

Aykaç, M., \& Adıgüzel, H. Ö. (2011). The effect of using creative drama as a method on student success in social studies courses. Journal of Kastamonu University Faculty of Education, 19, 297-314.

Brewer, J. A. (2007). Introduction to early childhood education: Preschool through primary grades (6th ed.). Boston: Pearson Education, Inc.

Çelen, İ., \& Vural, R. A. (2009). Drama in education and teaching English: A research on the fourth grade elementary students. Elementary Education Online, 8, 425-438.

Dalbudak, Z. (2006). A study on preschool teachers' using drama activities. Masters Thesis, Ankara: Ankara University Science Graduate School.

Dalbudak, Z., \& Akyol, A. K. (2008). Examining preschool teachers' drama activities in their curriculum. Journal of Çukurova University Social Sciences Graduate School, 17, 169-188.

Dellal, N. A., \& Kara, Z. (2010). Awareness levels of foreign language teacher candidates and teachers about drama techniques. Language Journal, 149, 7-29.

Erdoğan, G. (2006). A study on the effect of creative drama activities on 8th graders' levels of depression and self-concept. Masters Thesis, Ankara: Gazi University Educational Sciences Graduate School.

Fuford, J., Hutchings, M., Ross, A., \& Schmitz, H. (2001). Ilköğretimde drama. (Çev. Leyla Küçükahmet, Hande Borçbakan, S. SadiKaramanoğlu) Ankara: Nobel Yayın Dağıtım.

Girgin, T. (1999). Creative drama activities in preschool education institutions in Turkey. Masters Thesis, Ankara: Social Sciences Graduate School, Ankara University.

Gürol, A. (2003). Identifying the competence levels of preschool teachers and preschool teacher candidates related to drama. Journal of Firat University Social Sciences, 13, 147-165.

Harun, B. (2005). Attitudes of science teachers towards creative drama and their opinions on narration activities. Masters Thesis, Bolu: Abantİzzet Baysal University Social Sciences Graduate School.

Kaf, Ö. (2000). The effect of creative drama method on social skills in life study courses. Journal of Çukurova University Social Sciences Graduate School, 6, 173-184.

Kara, Y., \& Cam, F. (2007). The effect of creative drama method on the attainment of some social skills. Journal of Hacettepe University Faculty of Education, 32, 145-155.

Karacil, M. (2009). The effect of creative drama on student success in elementary school. Masters Thesis, Kars: Kafkas University, Social Sciences Graduate School.

Köksal, A. A. (2003). Drama and its importance. Journal of Turkish Educational Sciences, Gazi University, 2, 179-192.

Maden, S. (2011). Problems related to using the drama method in teaching Turkish. Journal of Adiyaman University Social Sciences Graduate School, 4, 107-122.

Miller, S. (1987). Some comments on the utility of metaphors for educational theory and practice. Educational Theory, 37, 219-227. 
doi:10.1111/j.1741-5446.1987.00219.x

Miles, M. B., \& Huberman, A. M. (1994). Qualitative data analysis: An expanded source book (2nd ed.). Thousand Oaks, CA: Sage.

Oğuz, A., \& Altun, E. (2011). A study on the relationship between teacher candidates' attitutes towards drama and their level of emphatic tecndencies. 2nd International Conference on News Trends in Education and Their Implications. Antalya.

Okvuran, A. (1995). The effect of creative drama on creating the modern person and on empathic tendencies. Journal of Ankara University Educational Sciences, 27, 185-194.

O'Neill, C., \& Lambert, A. (1995). Drama structures: A practical handbook for teachers. London: Hutchinson.

Ormanc1, Ü., \& Ören, F. Ş. (2010). Classroom teacher candidates' opinions related to using drama in primary school: An example of demirci faculty of education. Ankara University Journal of Faculty of Educational Sciences, 43, 165-191.

Oruç, S., \& Altın, B. N. (2008). Müze eğitimive yaratici drama. Çukurova Üniversitesi Eğitim Fakültesi Dergsisi, 3, 125-141.

Oxford, R. L., Tomlinson, S., Barcelos, A., Harrington, C., Lavine, R. Z., Saleh, A., \& Longhini, A. (1998). Clashing metaphors about classroom teachers: Toward a systematic typology fort he language teaching field. System, 26, 3-50.

doi:10.1016/S0346-251X(97)00071-7

Özdemir, S. M., \& Çakmak, A. (2008). The effect of drama education on prospective teachers' creativity. International Journal of Instruction, 1, 13-30.

Pinciotti, P (1993). Creative drama and young children: The dramatic learning connection. Arts Education Policy Review, 94, 24. doi:10.1080/10632913.1993.9936938

San, İ. (1996). A method that develops creativity and a discipline that improves the creative individual: Educational creative drama. Journal of New Turkey, 2, 148-160.

San, İ. (1999). The past and the present of creative drama in Turkey. Republic and child. 2nd National Children Culture Conference, Ankara: Ankara Üniversitesi Çocuk Kültürü Araştırma ve Uygulama Merkezi Yayınları.s., 267-273.

Saban, A. (2008). Primary school teachers' and their students' mental images about the concept of knowledge. Elementary Education Online, 7, 421-455.

Sağlam, T. (1997). Eğitimde drama. VI. uluslararasi eğitimde drama semineri. Drama maske müze. Yayına hazirlayan: Inci san. Ankara: Çağdaş Drama Derneği, 33-35.

Toy, B. Y. (2012). Perceptions of teacher candidates regarding the instruction of pedagocial courses by using drama method: The development and learning course example. International Journal of New Trends in Arts, Sports \& Science Education, 1, 125-136.

Üstündağ, T. (1997). The advantages of using drama as a method of education in elementary schools. Journal of Hacettepe University Faculty of Education, 13, 89-94.

Yıldırım, İ. N. (2008). Identifying elementary school teachers' competence and application levels related to creative drama. Elazığ: Firat University, Social Sciences Graduate School.

Yilmaz, G. C. (2006). Using drama method in science education. Masters Thesis, Denizli: Pamukkale University Science Graduate School. 